Florida International University FIU Digital Commons

FIU Electronic Theses and Dissertations

University Graduate School

4-23-2015

\title{
The Landscape Parks of Jane Austen: Gender and Voice
}

Lauren N. Rey

Florida International University, lcastaneda7979@gmail.com

DOI: 10.25148 /etd.FIDC000062

Follow this and additional works at: https://digitalcommons.fiu.edu/etd

Part of the Literature in English, British Isles Commons

\section{Recommended Citation}

Rey, Lauren N., "The Landscape Parks of Jane Austen: Gender and Voice" (2015). FIU Electronic Theses and Dissertations. 2237. https://digitalcommons.fiu.edu/etd/2237

This work is brought to you for free and open access by the University Graduate School at FIU Digital Commons. It has been accepted for inclusion in FIU Electronic Theses and Dissertations by an authorized administrator of FIU Digital Commons. For more information, please contact dcc@fiu.edu. 


\section{FLORIDA INTERNATIONAL UNIVERSITY}

Miami, Florida

THE LANDSCAPE PARKS OF JANE AUSTEN: GENDER AND VOICE

A thesis submitted in partial fulfillment of the

requirements for the degree of

MASTER OF ARTS

in

ENGLISH

by

Lauren N. Rey

2015 
To: Dean Michael Heithaus

College of Arts and Science

This thesis, written by Lauren N. Rey, and entitled The Landscape Parks of Jane Austen: Gender and Voice, having been approved in respect to style and intellectual content, is referred to you for judgment.

We have read this thesis and recommend that it be approved.

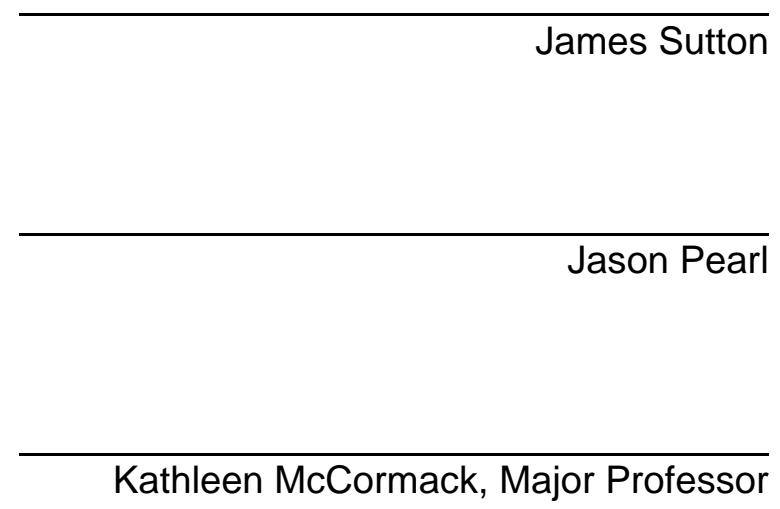

Date of Defense: April 23, 2015

The thesis of Lauren N. Rey is approved.

Dean Michael Heithaus
College of Arts and Sciences

Florida International University, 2015 


\section{DEDICATION}

I dedicate this thesis to my parents, especially my father, for always being a shining example of love, persistence and courage. Without their encouragement, the completion of this work would not have been possible. 
ABSTRACT OF THE THESIS

THE LANDSCAPE PARKS OF JANE AUSTEN: GENDER AND VOICE

by

Lauren N. Rey

Florida International University, 2015

Miami, Florida

Professor Kathleen McCormack, Major Professor

This thesis examines the function of specific garden features in Jane Austen's novels, particularly in the seminal texts Pride and Prejudice and Mansfield Park. Male power, politics and land ownership dominated eighteenth-century society. Despite this, Austen's woman protagonists utilize the tree avenues feature of landscape parks, voicing a need to redefine moral responsibility associated with land ownership. This thesis draws on the literary theories of gender studies and ecocriticism to examine garden spaces in Austen's texts, though the primary focus of the investigation relies on exploring the primary texts themselves with a historical approach. In addition to this secondary critical scholarship, this thesis utilizes resources such as eighteenth century garden histories and guides, background information on specific gardeners of the period, and typical landscape garden features as evidence. 


\section{TABLE OF CONTENTS}

CHAPTER

PAGE

I. Introduction 1

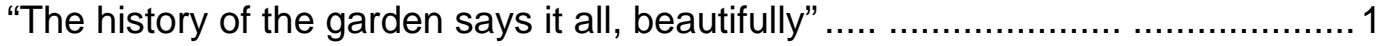

II. Moral Transformations in Sense and Sensibility, Northanger Abbey And Emma ...... 11

Elinor's Sense and Marianne's Sensibility ................................................ 12

Northanger Abbey: "You Have Learnt to Love a Hyacinth" ............................. 16

Emma: The Responsibility of the Wealthy ............................................... 20

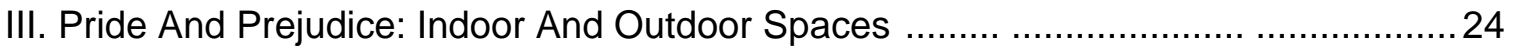

Rambles Through Dirt and Mud ......................................................... 24

The Indoor Spaces of Pride and Prejudice ............................................. 27

The Tree Grove: The Outdoor Environment Changes Everything . ................... 32

"I Know No Such Thing of the Practice of Elegant Females" .......................... 37

IV. Mansfield Park: Strong Statements On Stewardship ....................................... 44

Sotherton Court: "A Good Spot for Fault-Finding" .................................... 44

"One Likes to Get Out Into a Shrubbery" ................................................ 47

Fanny and Stewardship .................................................................... 53

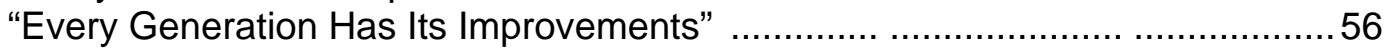

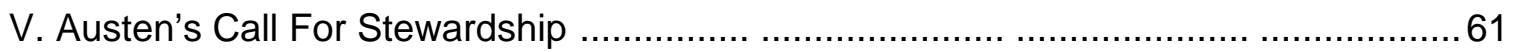

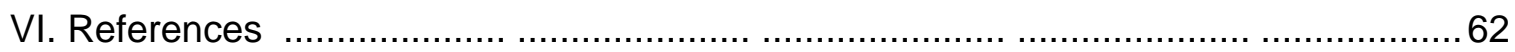




\section{Introduction}

"The history of the garden says it all, beautifully." - Tom Stoppard, Arcadia

\section{Critical scholarship recognizes the importance of the natural world in Jane Austen's}

novels ${ }^{1}$. Austen frequently used the quintessential country estate landscape garden as

the setting for key events in her novels. Critics posit that Austen explores the aesthetics

of these gardens in her work to develop characters. Scholars debate the eighteenth-

century politics inherently associated with improving such a landscape garden-- a topic

\footnotetext{
${ }^{1}$ Literature exists on Austen's descriptions of nature and her use of gardens. Most notable are Alistair M. Duckworth's "Mansfield Park and Estate Improvements: Jane Austen's Grounds of Being" and Jonathan Bate's The Song of the Earth, both of which discuss the topic of improvements to landscape gardens and the qualities prized by Austen in an eighteenth-century landscape improver. See also Richard Quaintance's “Humphrey Repton, 'any Mr. Repton,' and the 'Improvement' Metonym in Mansfield Park" which further discusses this idea of improvers, referring to Humphrey Repton in particular and his impact on eighteenth-century landscape gardens. Some critics focus on the importance of the Enclosure Movement to this topic of landscape parks, most notably Celia Easton's "Jane Austen and the Enclosure Movement: The Sense and Sensibility of Land Reform." Mac Griswold's "Planting the English Landscape Garden: There Were Flowers" discusses the common designs of landscape parks and popular flowers and shrubs that would have been used by landscape improvers. Rosemary Bodenheimer's "Looking at the Landscape in Jane Austen" discusses the way Austen's responses to nature establish various conditions of character. Various critics discuss the way that perspective becomes involved in a landscape in Austen's work, often symbolizing anything from the power that human beings exert over the land they own to the way that these spaces show the difference between male and female power in Austen's novels. For examples on this topic, see Julianne Pidduck's "Of Windows and Country Walks: Frames of Space and Movement in 1990s Austen Adaptations," Mary M. Chan's "Location, Location, Location: The Spaces of Pride \& Prejudice," Denis Cosgrove's "Prospect, Perspective and the Evolution of the Landscape Idea," Barbara Wenner's "'I have just learnt to love a hyacinth': Jane Austen's Heroines in Their Novelistic Landscape," and Ann Banfield's "The Moral Landscape of Mansfield Park." Christina Marsden Gillis' "Garden, Sermon and Novel in Mansfield Park: Exercises in Legibility" discusses the idea that gardens in Austen's novels yield meaning when read as texts within texts. Amy M. King's Bloom: The Botanical Vernacular in the English Novel deals with the transformation of Austen's female protagonists into marriageable prospects as a type of blooming, much like the flowers that litter Austen's garden descriptions. Finally, David MacWilliams' "Hurrying Into the Shrubbery: The Sublime, Transcendence, and the Garden Scene in Emma" discusses the sublime within the garden scenes of Austen's Emma.
} 
of discussion among several of Austen's characters-- and call into question the morality and ethics inheriting landowners of that time would have faced when planning these improvements.

Critics who participate in this discussion of Austen's techniques and aims in using the natural world, however, fail to explore how she specifically uses very particular landscape garden features, namely tree avenues, groves, and shrubberies. These three garden features emerge consistently in Austen's fiction, yet critics often brush them aside. The tree avenue is relegated as a private outdoor space, while the shrubbery and grove simply allow for romantic rendezvous between characters. Criticism denies the respect owed to these three garden features in Austen's work. They represent the active roles that Austen's woman protagonists take in eighteenth-century stewardship, and the opinions they voice concerning the shifting values of that century's inheriting generation of landowners.

Though Austen's books were published during the early nineteenth-century, many of the dominant ideas about gardens and gardening during her lifetime still revolved around the eighteenth-century landscape garden concept and the evolution of its features. Sue Farrant provides a time frame for this garden concept, placing "the principal period of park development... between 1750 and 1820, when, for example, Capability Brown ${ }^{2}$ was consulted by Lord Ashburnham, by Thomas Fuller and by Lord Sheffield" (Farrant 166). Humphrey Repton, the first publicly acknowledged landscape gardener, lived and worked from 1752 to 1818 (Batey 80). Austen was born in 1775 and died in 1817, aligning her lifetime with this period of garden productivity and one of its

${ }^{2}$ Capability Brown was a leading landscape architect of this period. His greatest achievement is often considered to be his influence on his pupil, Humphrey Repton. For more information on Capability Brown, see Mavis Batey's Jane Austen and the English Landscape. 
greatest contributors. Standard eighteenth-century garden terminology and design thus lend vital support to this thesis, as does the history of its development.

Austen's female protagonists, though varying in temper and spirit, are united by their strong passion for garden spaces. They each express their preference for a country home over a dwelling in a bustling city. In Persuasion, Anne Elliot expresses just such a wish when she learns that, as a consequence of debt, her family must let their country home, Kellynch Hall, and take a house in the city of Bath. She hopes instead for "a small house in their own neighborhood, where they might...still have the pleasure of sometimes seeing the lawns and groves of Kellynch" (12). Anne's character will wither over time in the urban streets of Bath if not for the gardens of Kellynch Hall. Her blooming is contingent on this outdoor space. Likewise, Emma Woodhouse prefers the quiet of her home in Highbury, never once expressing even a desire to partake in the diversions of London despite the privilege and ability that her wealth provides her. She is deeply rooted to her home and the countryside surrounding it. Elizabeth Bennet is very fond of walking through her home's surrounding countryside, while Eleanor often laughs at Marianne's "passion for dead leaves" at Norland Park (74). Each protagonist takes great pleasure in her natural surroundings.

Women's pleasure, however, was hardly a factor considered in the design of these grand and complex outdoor spaces; they were certainly never intended to hold any symbolic meaning for women like Anne and Emma. Though women were encouraged to enjoy the finished product, landscaped parks were created solely for the benefit of a family's first-born male child (Bell 473). Cultivated garden spaces, dominated by masculine attention to classical motifs and displays of wealth and power, functioned as a means for men to "internalize the harmony perceived... in nature" (Banfield 2). Visitors recognized a male landowner's power and wealth through the "cultivated 
property" or "culture's visual power" (Cosgrove 45). During the eighteenth century, the definition of the term 'culture' took root in a person's physical relationship with the earth, meaning "a cultivated field or piece of land" (Bate 3). Thus the park expressed to all visitors the culture of the landowning family's male line, linking their wealth and ambition to the excessive size and carefully manicured beauty of the property's grounds.

Alistair Duckworth claims that the measure of an estate's value during this period began to transform with the introduction of the idea of "improvement" to landscape parks. In previous decades land was a community space, with the Common supporting that community as a whole by providing a space for animals to graze (Easton 74). During the early 1800s, however, the value of male connection to inherited property centered on dominance, power, and the individual self rather than the tradition of community (Bell 472). The enclosure movement formed, calling for "a wall or fence or hedge" to be put up "around land to separate it from neighboring property" (Easton 73). With this new wave of thinking, men started questioning their responsibilities and priorities as landowners, putting themselves and their private tastes before the needs or concerns of the surrounding community. As Cecilia Easton argues in her article about the movement, wealthy owners chose privacy over social responsibility (Easton 74).

The park's improved design and key features conveyed powerful ideas about ambition and wealth. The renovation of the eighteenth-century landscape park included a dramatic departure from the previous style of English gardening, which was rigid with mathematical precision and straight, geometrical lines, following in the footsteps of the popular French royal court garden designs (Hobhouse 190). H.C. Darby remarks:

The gardens that were coming into being [in the seventeenth century] were of a very formal character. Andre le Notre who planned the layout at Versailles had many pupils in England, and the influence of his 
geometrical designs was very evident. Avenues and walks were laid out in straight lines, frequently radiating from one point, parterres were arranged in stiff and symmetrical patterns and trees were cut and clipped with precision. (Darby 389)

The eighteenth-century English landscape park marked a strong departure from these earlier adaptations of French style garden design: "Geometry, both in layout and in plant clipping, was gradually abandoned in favor of natural contours and free-growing, untortured shapes" (Hobhouse 193). With its new, sloping hills and curving lines, the English landscape garden defied all previous tastes, as

Serpentine and meandering paths, 'green openings like meadows' and less regularly shaped 'groves' and shrubberies (in which flowers were also found) began to take the place of the stereotyped wildernesses; they were no longer to be planted like orchards, 'with their trees in straight lines ranging every way, but in a rural manner, as if they receiv'd their situation from nature itself'. (Hobhouse 190)

Key garden features such as the wilderness and shrubbery cropped up in place of the rigid avenues of "regular yews and holly" that once reached out toward the English sky (Hobhouse 190). These substitutions marked a new path for the English garden and an official departure from the previously fashionable French style.

New ideas in the field of landscape design soon followed this transformation of the landowner's role. The style of landscape gardening associated with Capability Brown and Humphrey Repton grew in popularity among the wealthy landowning class. Brown's new style soon visually represented the shift in English understanding of inherited property, often featuring such dramatic changes as stripping away entire avenues of trees to make room for human-made lakes and hills (Duckworth 29, 32). An eighteenth- 
century semblance of abandon replaced the iron seventeenth-century precision. The idea was to take the beauty of nature where it offered the best advantage and enclose it within a carefully constructed park. Landscape parks were artfully crafted to give the person enjoying the garden the feeling of walking in a place left undisturbed by human hands, while allowing the owner to feel powerful for having purposely recreated what nature haphazardly threw together ${ }^{3}$. Landscape parks reflected ownership and private definitions of natural beauty, providing a striking contrast to the previous community Common and French style seventeenth-century pleasure gardens.

Austen's novels reflect these changes in attitude occurring during her lifetime. In Mansfield Park, for example, Fanny Price observes the various conversations about park improvements that take place between her companions. Through these dialogues, Austen expresses strong views of Humphrey Repton, the leading landscape designer of the period. A distinction surfaces between the values of the traditional landowner (a role held by Fanny's aging and absent uncle) and the younger generation of inheriting landowners, as they discuss the merits or disadvantages of Repton's work. Duckworth notes Austen's awareness of this distinction in attitude, writing that country estates in her work "function... as indexes to the character and social responsibility of their owners" (Duckworth 25). In Austen's texts, the behavior of a landowner towards his grounds becomes, in other words, a measure of his character and moral values.

In the midst of this changing definition of land ownership, Austen believed in the moral and social duty of a landowner to act as a steward. Critic Jonathan Bate writes in The Song of the Earth that "for Austen, 'culture' is located in a landscape and a mode of agriculture, not merely in manners and aesthetics. Her ideal England is one in which

\footnotetext{
${ }^{3}$ See Elizabeth K. Helsinger's Rural Scenes and National Representation: Britain, 1815-1850
} 
social relations and the aesthetic sense... are a function of environmental belonging" (7). Like Duckworth, Bate draws connections between the landowner's interpretation of his social responsibility and its very real, actual cultural impact ${ }^{4}$. Bate explains that Austen distinguishes between two types of landowners: one who acts as a good steward and one who profits personally from an irresponsible absenteeism. According to both Bate and Duckworth, Austen only finds the first type of estate owner acceptable because he works in keeping with his traditional social responsibility, ensuring his land provides for the community without unnecessary, vain or dramatic improvements. She censures the second type of landowner's behavior, for

Instead of having a responsible, nurturing relationship to the soil, the improver has a purely aesthetic one. He regards his estate as a pleasure garden rather than as land which needs to be managed with care and consideration. (Bate 549)

Austen, according to Bate, viewed improvements as demonstrating a lack of concern and appreciation for the land's history and value.

Both Duckworth and Bate fail to discuss the role women might have played in this question of land ownership. While Duckworth suggests that women played a role as future mistresses of the property, he also clarifies that the male inheritors of the estate are ultimately the architects of the final changes a landscape park may undergo (Duckworth 25). Women, then, have little to no power in shaping the new political and social meaning of these vast parks and garden spaces. Bate, on the other hand, leaves women out of this responsibility completely, referring only to the male landowner

\footnotetext{
${ }^{4}$ Alistair Duckworth is the pioneer of historical garden research in Jane Austen's works, while Jonathan Bate offers eco-critical arguments on this topic of Austen's texts. His research makes him a source which naturally works well alongside Duckworth, as both agree on key factors about Austen's use of eighteenth-century landowners and their meaning in her texts.
} 
characters in Austen's novels. For Bate, the woman protagonists have no place in the discussion.

This oversight by Duckworth and Bate is understandable, since women could not inherit property during the Regency period. Yet Austen's woman protagonists clearly feel a strong connection to these landscape parks in a way that goes beyond a mere socially acceptable, romantic fascination with the beauty of nature. These cultivated masculine spaces serve a stronger purpose for these women by inspiring critical conversation between the characters, and acting as the settings of pivotal scenes, propelling the action of several of Austen's plots forward.

Such scenes can sometimes effectively change the entire direction of the action in a given text, putting the woman protagonist on a new path towards self-improvement. In Pride and Prejudice, for example, Elizabeth Bennet receives a letter from Mr. Darcy while walking in the tree avenue at Rosings Park, a setting which influences her changing opinion toward his character and opens new possibilities for both their relationship and her future. In Emma, a picnic and strawberry picking at Donwell Abbey reveal new information to Emma Woodhouse about the character of Jane Fairfax and Jane's true feelings about accepting a position as governess to a wealthy family. This step begins to forge an unlikely friendship between them. In Mansfield Park, an excursion to review the grounds of Sotherton Court allows Fanny Price a chance to see certain relationships build among her acquaintance which go unnoticed by other characters. These relationships prove paramount in deciding Fanny's fate and that of some of her closest relatives.

Austen's placement of many such pivotal scenes in a landscape park-- a socially recognized masculine space-- in novels told from the focalization of strong woman protagonists thus must have a deeper meaning than the mere convenience of a beautiful 
location. Where Duckworth explores the function of the landscape park as only "an index to the character and social responsibility" of their male owners, all of these combined experiences show that women, too, can be measured by that same index (Duckworth 25). The lovely walks and lush, rolling hills on the estates provide a social education not anticipated when male hands designed landscape garden features. The landscape park teaches these women about both themselves and their roles in society.

Austen goes a step further in her novels, employing a specific space within the landscape garden to demonstrate her ideas about female responsibility and stewardship. Despite the socially accepted norm that dictated masculine control of the landscape garden, Austen's woman protagonists utilize the tree avenues of landscape parks to voice a social need to redefine the moral responsibility that should come with land ownership. They do so by drawing on the past traditional idea of a community rooted in this garden feature, making use of the avenue as a firm and established resource during a time of ever-shifting values and ideals. The avenue represents a space where these women can recognize the problems that come with privatized land ownership. Several of Austen's novels take up the discussion of responsible ownership through the woman protagonist's appreciation of the natural, unimproved landscape of the parks. The male landowner demonstrates his appreciation and natural worth by forgoing ambitious improvements that would enhance his vanity rather than the functionality of the land itself.

As Bate suggests, Austen chooses to focus on the negatives of acting as an absentee owner, demonstrating in her texts how a more sincere relationship with nature as a steward allows for personal moral improvement. Stewardship translates in her work into an improvement for the society as a whole, as its wealthy leaders guide the community by example. Returning to an idea of a community that benefits from the care 
and guidance of its wealthiest members, in other words, is better for everyone. Wealth should be defined by a greater responsibility toward property, rather than a dismissal of that responsibility for selfish enterprises.

Issues surrounding the purpose of the changes to gardens include the manifestation of wealth and power in male characters, the appreciation of the values of the past and of responsible stewardship in women characters, notably Fanny in Mansfield Park, and the differing ways the inclusions of the shrubberies (newly introduced during the temporal settings) measure the dignity of Elizabeth in Pride and Prejudice but the frivolity of Mary Crawford and Lady Bertram in Mansfield Park. Hence, although excluded from exercising the power of ownership over estate parks during Austen's temporal settings, their specific components provide areas for evaluating Austen's characters for their dignity and moderation, their concern with wealth and power, and their attitudes toward land stewardship. 


\section{Moral Transformations in Sense and Sensibility, Northanger Abbey and Emma}

"For a blissful Paradise of God the garden was." - Paradise Lost, John Milton

Many of Austen's novels make this desire for traditional, responsible stewardship obvious. Her woman protagonists enjoy walking in fresh air, admire their natural surroundings, and praise gorgeous countrysides. As their future husbands meet and court them, these women not only appreciate nature, but also thrive in it. Indeed, moments spent in outdoor gardens often inspire the woman protagonists with a fresh perspective on their own actions, as well as helping them see the actions of others more clearly. During their ramblings in nature, they undergo a moral transformation that allows them to take their place as married women and co-leaders of their community, worthy of being true stewards of the land they now share with their spouses. In each case, the landscape park teaches these women about both themselves and their roles in society.

Although Pride and Prejudice and Mansfield Park provide the most important garden-related characters and plots, Sense and Sensibility, Northanger Abbey and Emma also develop character through their relations with natural spaces. ${ }^{5}$ In Sense and Sensibility, Marianne Dashwood undergoes this moral transformation when she learns to incorporate some of her sister Elinor's characteristic sense and patience into her thinking. This transformation allows Marianne to soften her ultra-romantic notions of nature and love, and allows her the opportunity to accept Colonel Brandon as a worthy

${ }^{5}$ Sense and Sensibility, Northanger Abbey and Emma all offer scenes in which characters develop in natural settings, but relate less directly to the two components, specifically tree avenues and shrubberies, important to Pride and Prejudice and Mansfield Park. Hence full chapters will deal with those two novels individually. Because Anne Eliot suffers in exile from Kellynch Hall in Persuasion, her experiences rarely include the kind of estate in Austen's other novels. 
husband. In Northanger Abbey, Catherine Morland develops her fanciful notions about the abbey's family when she first enters the abbey property. The grounds feed her wild imagination and inspire her incredible notions about the family's dark history of murder. In Emma, Emma Woodhouse is shamed by Mr. Knightley after she mistreats a socially inferior neighbor at Box Hill. Knightley's lowered opinion of her helps Emma recognize her misbehavior, and correct her faults so that she may, once again, be a moral pillar of her small Highbury neighborhood. Her moral change helps her win back Knightley's esteem, thus allowing them to join their estates through marriage at the novel's end.

\section{Elinor's Sense and Marianne's Sensibility}

Marianne Dashwood learns some of her moderation through relating to natural settings. Although she shows a proper respect for the avenue of trees at Norland, as she relinquishes her excessive romanticism her progress towards successful stewardship occurs alongside a taming of her emotional attachment to nature and her preference for the tamer areas of the parks. Marianne, "sensible and clever," on the other hand "has no moderation," and is "everything but prudent" (4). When she must leave her home after her father's death, Marianne's greatest concern is the loss she feels for the land surrounding her home:

'Dear, dear Norland!' said Marianne as she wandered alone before the house on the last evening of their being there; 'When shall I cease to regret you! ... And you, ye well-known trees! But you will continue the same. No leaf will decay because we are removed, nor any branch become motionless, although we observe you no longer! No, you will continue the same: unconscious of the pleasure or the regret you occasion and insensible of any change in those who walk under your shade! But who will remain to enjoy you?' (22). 
In her final sorrowful walk through the property, Marianne recognizes one of the innate problems with land ownership: a change in hands from one generation to the next inevitably changes how the land is viewed, appreciated and cared for.

Yet Marianne herself "has no moderation" (4). She recognizes this problem through eyes clouded by romantic notions and sensibilities. Her dramatic love for Norland's grounds extends so far as to allow her to appreciate even dead, winter leaves with enthusiasm: "Oh! With what transporting sensations have I formerly seen them fall! How have I delighted as I walked to see them driven in showers about me by the wind! What feelings have they, the season, the air, altogether inspired!" (74). She then states that her "feelings are not often shared, not often understood" by those around her (74), possibly because her passion, while heartfelt and deep, borders on the ridiculous.

Where she celebrates hills and wind, others remark on the dirt and cold. Marianne lives in a world of her own, modifying what she sees to suit her romantic tastes.

Other characters' descriptions illuminate this aspect of her character. Her half brother John, for instance, inherits the estate from Marianne's late father. According to John, "There is still a great deal to be done [to Norland]. There is not a stone laid of Fanny's greenhouse, and nothing but the plan of the flower garden marked out" (191). When asked about the situation of the greenhouse, John replies, "The old walnut trees are all come down to make room for it. It will be a very fine object from many parts of the park, and the flower garden will slope down just before it, and be exceedingly pretty" (191). Where Marianne finds perfection in the natural state of Norland, John feels the estate needs vast improvements to make it livable. The greenhouse will not benefit the property, but rather please his wife, Fanny. Likewise, the flowers put aside the design created by nature and embrace a man-made blueprint, their arrangement pleasing the owner's eye. For John, Norland is now his to command and change. 
Marianne is right to mourn these changes, as they occur solely for John and Fanny's benefit. Yet her romantic notions, her "passion for dead leaves," hinder her from seeing the gravity of the situation from the perspective of a steward (74). For Marianne, the loss of the trees in the avenue is purely emotional, making her just as selfish as John. She mourns the loss of her ability to enjoy them privately, not their loss as a longstanding feature of the property's tradition and culture.

Austen's narrator laments this reckless disregard for tradition and function in a property. For Marianne to prove her worth and value as a steward, she must first undergo that moral change that Austen crafts for each of her woman protagonists. With this aim Austen then crafts Elinor's character, an opposite in most respects to Marianne's. Where Marianne celebrates all things with strong passion and joy, Elinor possesses "a strength of understanding and coolness of judgment which qualified her, though only nineteen, to be the counselor of her mother" (4). In the wake of the family's many misfortunes throughout the novel, Elinor can chart a course that keeps the family in a small but comfortable home, and allows them to stretch their simple means to buy food and live in relative comfort. As Marianne undergoes the various tragedies that strike her in her search for love, she comes to rely on that steadfast sense and cool judgment from Elinor. If Marianne can achieve her place as a leader of society, a steward who works in kinship with the land for the sake of right rather than romance, she must learn to balance her sensibilities with Elinor's sense and steady prudence.

By the novel's close, the handsome but rakish Mr. Willoughby rejects Marianne painfully. Her sorrow over this rejection leads to self-induced poor health. Marianne and Elinor visit a friend's estate, Cleveland, on their way home from a journey to London. Cleveland, a modern house, "had no park, but the pleasure grounds were tolerably extensive; and like every other place of the same degree of importance, it had its own 
shrubbery and closer wood walk" (255). During her stay, Marianne spends her time at Cleveland frequenting

not merely the dry gravel of the shrubbery but all over the grounds, and especially in the most distant parts of them where there was something more of wildness than in the rest, where the trees were the oldest, and the grass was the longest and wettest (258).

Marianne persistently avoids the safer, more organized parts of the property specifically set aside for female enjoyment and exercise in favor of spots where the trees are older, more connected with nature's natural wildness. Unlike other heroines, Marianne dramatically seeks out these locations as a soothing balm for her broken heart, which demands complete solitude in nature. In trying to escape into these features of the property, she invariably leaves behind a very important trait prized by Austen by all stewards: common sense. Again, Marianne proves the foolishness of her impractical sensibilities. In this case, all her solitary ramblings through the property leave her with an illness that nearly kills her, once again validating the harm resulting from Marianne's passionate notions.

After her near-fatal illness, Austen leads Marianne on a path where she must grow and learn from Elinor's steadier example. While Elinor does not fall into fits of rapture as she observes the natural countryside around her, she does appreciate the beauty of a landscape park, and recognizes the value of preserving its traditions. John's proposed improvements to Norland Park, for example, leave her shaken. Where Marianne would have protested violently, Elinor prudently chooses instead to "keep her concern and her censure to herself" (191). After her illness, Marianne comes to recognize the value of Elinor's prudence, claiming that the two sisters will take long walks together every day, and that Marianne hopes to gain, in the course of the next 
year, a "great deal of instruction which [she] now felt [herself] to want" (291). Marianne recognizes her deficiencies, and by comparing her conduct to Elinor's, hopes to learn how to correct her faults.

Marianne plans to relinquish her stronger passions, allowing herself to appreciate the world around her with a deeper sense of introspection, and a release of those strongly held romantic sensibilities. Her love of nature turns from ridiculous and dramatic to a finer appreciation of that beauty that surrounds her countryside home. As she pursues this worthy goal, Austen tells us that

Marianne Dashwood was born to an extraordinary fate. She was born to discover the falsehood of her own opinions, and to counteract by her conduct her most favorite maxims. She was born to overcome an affection formed so late in life as at seventeen, and...voluntarily to give her hand to another... Instead of falling a sacrifice to an irresistible passion, as she once had fondly flattered herself with expecting...she found herself at nineteen submitting to new attachments, entering on new duties, placed in a new home, a wife, the mistress of a family, and the patroness of a village. (322)

By giving up her overly dramatic expectations for love and nature, Marianne undergoes a moral transformation, and becomes mature enough for reception into her new home and her role as mistress and role model for the village of Delaford as Colonel Brandon's new wife.

\section{Northanger Abbey: "You Have Learnt to Love a Hyacinth"}

In Northanger Abbey, Catherine Morland learns an equally difficult lesson concerning excessive romanticism. At the same time that she gradually acquires a less tomboyish appreciation for flowers, she makes her major mistake when she conceives her 
erroneous plot about General Tilney based on her conclusions as to why he avoids his wife's favorite walk among the Scotch firs.

Catherine mirrors Marianne's flare for the dramatic, though she claims ignorance of the picturesque and has no taste for "watering a rose-bush" (21). Raised as a tomboy with a love of shocking novels, Catherine dreams of Northanger Abbey's adventures and secrets long before she journeys towards it. She hopes the abbey is "a fine old place, just like what one reads about" (151). Catherine echoes Marianne's familiar brand of whimsy and romance.

After extending an offer to visit the abbey, Henry Tilney teases Catherine about her love of fiction: "You have formed a very favorable idea of the abbey... and are you prepared to encounter all the horrors that a building... may produce? Have you a stout heart? Nerves fit for sliding panels and tapestry?" (151). His banter shows he recognizes her affinity for drama and mystery, and his manner shows he finds her ignorance charming and attractive (112). Yet her ignorance also betrays her immaturity, and makes her an unsuitable choice for a wife and mistress of a home and staff.

In the course of their acquaintance, Tilney and his sister Eleanor influence Catherine, helping her access knowledge and behavior suitable for a young, eighteenthcentury woman. This knowledge previously has lain out of her reach because of her modest upbringing as one of ten children in a rambling country parish. The Tilneys are inspired by their shared affection for her, helping Catherine correct some of these flaws. Eleanor's company exposes Catherine to new ideas about the natural world, and helps her appreciate that world with sentimentality appropriate for a woman: "I have just learnt to love a hyacinth...your sister taught me; I cannot tell how...I am naturally indifferent to flowers." (166). In Mr. Tilney's eyes, his sister influences positively, helping polish and reform Catherine's rougher mind. He says, 
But now you love a hyacinth. So much the better. You have gained a new source of enjoyment, and it is well to have as many holds upon happiness as possible. Besides, a taste for flowers is always desirable in your sex, as a means of getting you out of doors, and tempting you to more frequent exercise. (166)

Society expects Catherine to appreciate beautiful flowers, such as those found in the shrubbery or copse of a typical garden. While Tilney finds her eccentricity charming, he still agrees with these ideas.

Catherine, on the other hand, refuses to accept these views of femininity. She says "But I do not want any such pursuit to get me out of doors. The pleasure of walking and breathing fresh air is enough for me, and in fine weather I am out more than half my time." (166). She happily enjoys nature despite her lack of ladylike botanical knowledge, relishing the chance of exercise. While she may learn to appreciate these feminine arts, her natural disposition rejects such frivolous principles for her sex. Catherine's pure appreciation for the natural world comes from the natural pleasure its freedom affords her.

Like Marianne, however, Catherine romanticizes and fantasizes the natural world. When she arrives at Northanger Abbey, she lets her emotions and wild imagination roam free, forming awful and outlandish ideas about her hosts. The beauty of the abbey's grounds strike her as she observes them for the first time:

The whole building enclosed a large court...The remainder was shut off by knolls of old trees, or luxuriant plantations, and the steep woody hills rising behind, to give it shelter, were beautiful...she had never seen any gardens at all equal to them before... [They approached] a thick grove of old Scotch firs, and Catherine, struck by its gloomy aspect, and eager to enter it, could not, even by the general's disapprobation, be kept from stepping forward. (169-171). 
The presence of healthy old trees denotes a healthy estate, a perfect climate for Catherine's continued education with the Tilneys. Yet all the beauty around her only inspires Catherine, with her love of fantastic novels, to assume the worst about General Tilney, Eleanor's father. When he scorns to join the two women on this walk through the old Scotch firs, a favorite walk of the late Mrs. Tilney, Catherine suspects the general of having mistreated his late wife: "he did not love her walk; could he therefore have loved her?" (172). By the time the group returns from their tour of the grounds, Catherine's imagination has carried her away, fantasizing the worst about the general's treatment of his late spouse: "Catherine attempted no longer to hide from herself the nature of feelings... and what had been terror and dislike before, was now absolute aversion" (173). Like Marianne, Catherine's romantic notions take her on a perilous path, placing her in danger of losing the Tilneys' respect.

The loss of respect occurs when Henry Tilney discovers Catherine's shocking ideas. He loses his faith in her, and her reflections on his family's potential history disappoint him. Her ideas, once charming, are now outrageous and insulting, leading Tilney to feel shame at her behavior.

Catherine recognizes the error of her thinking as a result of Tilney's disappointment. Her wild imagination now tamed, Catherine feels guilty and recognizes the horror of her fantasies. When Tilney censures her thoughts as unfair and entirely ridiculous, as well as insulting to his family, Catherine's world comes to a crashing halt. At that moment, 'the visions of romance were over. Catherine was completely awakened. Henry's address, short as it had been, had more thoroughly opened her eyes to the extravagance of her late fancies than all their several disappointments had done" (188). Like Marianne's violent awakening after her near-death experience, Catherine is shamed into a realization that her romantic notions harm good people who treat her well. 
The recognition cures her, making her a more mature version of herself, ready to put aside childish fantasies from her novels and replace them with the truth of the life around her. Once she achieves this, she can rekindle respect and admiration from Henry Tilney, who breaks with his father in order to propose marriage to her.

\section{Emma: The Responsibility of the Wealthy}

Emma Woodhouse, though more sensible than her fellow protagonists, needs a moral push to learn humility and recognize her flaws. She, too, learns her hardest lessons in connection with natural spaces. Despite Mr. Knightley's resistance to Mrs. Elton's skewed ideas of what makes up a pleasant strawberry picking, and the discomforts that prevail during the event, Emma begins to appreciate the value of Jane Fairfax on the property of the estimable Mr. Knightley. ${ }^{6}$ On the other hand, she commits her worst offence at Box Hill, a spot where Knightley's landowning authority does not prevail.

During a picnic to Box Hill7, Emma allows herself the luxury of making fun of Miss Bates, a poor spinster long acquainted with the Woodhouse family. Upon her arrival to Box Hill, Emma describes the view around her, deciding "it was a sweet view- sweet to the eye and the mind. English verdure, English culture, English comfort, seen under a sun bright without being oppressive" (312). The hill models what it means to be English, and Emma connects with that definition as she takes in the view, establishing herself among the ranks of English wealthy landowners. Her elite social and economic status sets her apart from Austen's other protagonists. Yet Emma must, like the other

\footnotetext{
${ }^{6}$ Jonathan Bate thoroughly discusses Mr. Knightley's exemplary stewardship.

${ }^{7}$ Box Hill is an open hill top best known for picnicking. Though not a typical landscape garden, the space is open and untouched by human hands, left to be enjoyed by the public for its natural beauty and spectacular views. In this sense, it performs the same function as the tree avenues of other landscape parks discussed in this thesis.
} 
protagonists, turn her strengths into weaknesses in order to deserve that place in the English ranks.

During the picnic, Emma starkly reveals flaws which make her unworthy of safeguarding English culture and verdure. She openly insults Miss Bates, a poor spinster, leaving her to the laughter of the others in the party. Mr. Knightley, Emma's good friend and social equal, later rebukes Emma for her harsh comments, saying I cannot see you acting wrong without a remonstrance. How could you be so unfeeling to Miss Bates? How could you be so insolent in your wit to a woman of her character, age, and situation? ... were she prosperous, I could allow much...were she a woman of fortune, I would leave every harmless absurdity...were she equal in your situation- but, Emma...she is poor...Her situation should secure your compassion. It was badly done ...to have you now, in thoughtless spirits and the pride of the moment, laugh at her, humble her- and before others, many of whom.... would be entirely guided by your treatment of her.

Knightley's anger arises chiefly from Emma's role as a social model. Her wealth gives her a prominent place in society, and makes her a moral leader of her community. By insulting Miss Bates in front of the others in her social group, Emma gives them permission to censure others who are their social inferiors, crassly and publicly laughing at them without feeling.

This exchange demonstrates Emma's need for growth and maturity. That the rebuke comes from Mr. Knightley heightens Emma's urgency for moral reformation. Emma's visits to Knightley's estate, Donwell Abbey, reveal her great respect for Mr. Knightley. His friendship and good opinion are valuable to her. During the strawberrypicking party at Donwell, Emma understands and accepts the importance of the 
Knightley family in Highbury society when she views the care Knightley has taken with his grounds:

its ample gardens stretching down to meadows washed by a stream of which the Abbey, with all the old neglect of prospect, had scarcely a sight- and its abundance of timber in rows and avenues, which neither fashion nor extravagance had rooted up...It was just what it ought to be, and it looked what it was; and Emma felt an increasing respect for it as the residence of a family of such true gentility, untainted in blood and understanding. (310)

Emma recognizes Knightley's goodness, and that his goodness springs from his respect for the land and his traditional view of stewardship. Knightley cares more about making the land productive and stable, than for its appearance to strangers. He rejects fashionable and extravagant improvements. He is a just master, good to his tenants. His trees, lined up in careful avenues, demonstrate his family's deep respect for tradition. The avenue is genteel and prosperous, owing to Knightley's hard work and effective stewardship.

The Box Hill confrontation urges Emma to reconsider her own role in her community. Through Knightley's comments, Emma recognizes her need to move from frivolous matchmaker (a role she selfishly takes up as a fun past time) to a more responsible member of the community, looking out for those around her with opened eyes and a renewed spirit. Only at this time can she marry Knightly, himself a responsible landowner.

All these characters experience their moral transformations in natural settings: Marianne in her rambles through Cleveland, Catherine in the walk among the Scotch firs at Northanger Abbey, and Emma at Box Hill. Elizabeth Bennet shares their need for moral growth. Her walks through Rosings Park, Pemberley and Longbourn demonstrate 
the tree avenue's emblematic transformation of the woman protagonists in Austen's novels. Through these walks, the protagonists embrace the cultural values that come with traditional stewardship, so highly prized by Austen. 
III. Pride and Prejudice: Indoor and Outdoor Spaces

"Bring me a shrubbery!" - Monty Python and the Holy Grail

Pride and Prejudice initiates the notions later cemented in Mansfield Park about responsible stewardship. While Fanny Price never wavers in her understanding of good stewardship, Elizabeth Bennet must let her environment transform her before she can come to understand the term. Her ensuing education alters her view of herself within the landscape that surrounds her and generates Elizabeth's desire for active participation in a healthy, responsible stewardship. Her mistakes exhibit how Austen's tree groves and shrubberies represent the difference between responsible stewards and absentee landowners of the eighteenth century.

\section{Rambles Through Dirt and Mud}

From her walk through the wild countryside to her sick sister's bedside to the appreciation of Darcy nourished by her first view of Pemberley, Elizabeth sustains positive relations with nature. But her greatest victory comes in the park at Longbourn where she meets Lady Catherine's attack with dignity and triumph. Where Lady Catherine perceives a "wilderness," the narrator calls the area a copse, a word often referred as a synonym for shrubbery by several online Thesaurus sites (300). ${ }^{8}$

In Austen's Pride and Prejudice the landscape garden demonstrates Elizabeth Bennet's development as a strong-minded, independent woman protagonist with her

\footnotetext{
${ }^{8} \mathrm{~A}$ voice crying in the wilderness alludes to St. John the Baptist and many explanations of the phrase emphasize the correctness of the voice among other erroneous opinions. Here Lady Catherine holds the wrong opinion, while the use of the word wilderness, prominent in the Biblical allusion, ironically demonstrates both her over-confidence and the falseness of her opinions about Elizabeth.
} 
own strong sense of personal values. From the novel's start, Elizabeth establishes herself as a protagonist who relishes stepping outside of social norms, placing her affection for her sisters and friends before any particular rule of decorum. Elizabeth's three mile walk to Netherfield Park to visit her sick sister, Jane, marks the first instance where this trait occurs in the novel. Elizabeth crosses "field after field at a quick pace, jumping over stiles and springing over puddles with impatient activity, and finding herself at last within view of the house, with weary ankles, dirty stockings, and a face glowing with the warmth of exercise," (27). Ignoring the codes of conduct of her time which dictate sobriety and docility in women, Elizabeth boldly ventures forth through dirt and mud to lift her sister's spirits, even allowing herself the freedom of "jumping" and "springing" in a kind of reckless abandon, enjoying her time in this natural environment with great energy. This first experience with the natural world sets the standard with which Elizabeth experiences nature throughout the rest of the novel.

Likewise, her reception at Netherfield Park sets the standard for Elizabeth's reception by the rest of female society. She earns their censure because of the way she chooses to enjoy and make use of the natural world. Mrs. Louisa Hurst remarks to her sister, Miss Caroline Bingley, that Elizabeth "really looked almost wild...I hope you saw her petticoat, six inches deep in mud... and the gown which had been let down to hide it, not doing its office," (29). Though Elizabeth strives to fit to a degree within the standards of her society by trying to hide the evidence of her walk with the lowering of her gown, she cannot hide that she experiences nature in a way that energizes and excites her.

Undoubtedly, Elizabeth's femininity makes this experience of nature unacceptable. According to eco-critic Robert Kern, "exposing oneself to nature, in these terms, at least if one is woman, is tantamount to a serious violation of acceptable 
civilized behavior" (Kern 262). Yet what makes her behavior 'uncivil' to begin with? The Bingley sisters' understanding of the term "culture" answers this question.

Jonathan Bate discusses the evolution of the word "culture," particularly during Austen's lifetime. Originally signifying "a cultivated field or piece of land," the term grew in the sixteenth century to encompass the idea that

as the soil is improved and made productive by tillage, so the mind and manners may be improved by education and training. The word is thus removed from the earth and linked to the advance of society... cultivation comes to mean civility, a word which has its root in Latin civilis, meaning of, or pertaining to, the city. (543) Bingley's sisters subscribe to this newer understanding of the term culture, considering themselves civilized as a result of their feminine, city education, an education that includes valuing the social rules Elizabeth so quickly disregards. The protagonist's strength of character separates her from the other women, making Elizabeth place more emphasis on the virtuous purpose of a walk rather than its superficial effects on her clothing. She never concerns herself with how she looks when she arrives at Netherfield Park; her only concern lies in verifying her sister's condition for herself, and assuaging Jane's discomfort during her illness. She disregards the rules of propriety.

Kern discusses the importance of this particular passage, pointing out that Austen's description of this walk "gives us direct access to a physical environment that few women, in the genteel world of the novel, ever want or have to deal with," (Kern 262). Elizabeth's particular method of enjoying an outdoor environment contrasts her with the two other city women. The manners of the characters as they walk around the grounds at Netherfield heighten this contrast, with the group choosing a shrubbery as 
the setting for their conversations ${ }^{9}$. Just as city-bred Mary Crawford chooses the shrubbery in Mansfield Park, Bingley's sisters choose to walk along the more private shrubbery paths at Netherfield, even demonstrating their grasp of civility by physically blocking Elizabeth's ability to join them in the tight space. Their efforts are wasted, however, as Elizabeth mirrors Fanny Price by rejecting the crowded, superficial shrubbery, quitting it for a space in the garden free of this particular definition of culture: "she ran off gaily, rejoicing as she rambled about" (45). Elizabeth, though clearly grasping and executing the concept of civility throughout the novel, here proves that she also lives within a society that still values the origins of English culture. The protagonist experiences nature rambunctiously, free of any concern about social rules of etiquette. Getting away and being alone within the landscape garden at Netherfield remains her chief concern, leaving civilized society and its shrubbery behind her.

\section{The Indoor Spaces of Pride and Prejudice}

Elizabeth attempts recreating the freedom experienced during this first walk when she later passes unaccompanied through the larger landscape gardens of Pride and Prejudice. This proves difficult as she clashes with Fitzwilliam Darcy, an eighteenthcentury property heir visiting her neighborhood, who consistently challenges Elizabeth's perception of the world around her. Elizabeth's first impressions of him render Darcy as a member of the new generation of absentee landowners Austen censured. His elevated opinion of himself and superiority to others in the novel, as well as his pride in his inherited estate, makes him a more serious version of Mr. Rushworth of Mansfield Park.

\footnotetext{
${ }^{9}$ The significance of the shrubbery is discussed at length in the Mansfield Park chapter of this thesis.
} 
Despite everyone's predisposition to like him because of his considerable wealth, Darcy quickly earns a decidedly negative reputation in Hertfordshire:

Mr. Darcy soon drew the attention of the room by his fine, tall person, handsome features, noble mien...till his manners gave a disgust which turned the tide of his popularity; for he was discovered to be proud, to be above his company, and above being pleased; and not all his large estate in Derbyshire could then save him from having a most forbidding, disagreeable countenance, and being unworthy to be compared with his friend [Mr. Bingley]...and Elizabeth remained with no very cordial feelings toward him. (7-8)

From his entrance into the text, Darcy's behavior brands him as a member of an elite, emerging generation of inheriting eighteenth-century landowners. Darcy sets himself apart in a negative way, demonstrating the inability of wealth to save a person from social stagnation if the proper attitude and manners are wanting.

Darcy's pride and snobbish behavior at this first Hertfordshire ball supports the seeming truth of Elizabeth's first impressions of him. The gentleman stops short of sneering at the people gathered for the ball, likewise judging them based purely on the aesthetics of the country scene before him. This calculation of aesthetics supports perceptions of Darcy as an absentee landowner, concerned only with the importance of his own opinion, an opinion drawn from a superficial perspective. As the text progresses, this first understanding of Darcy's proud, conceited personality strengthens as Elizabeth's many experiences and conversations with him take place. The more time she spends with him, the firmer her notions of his character are fixed.

Setting plays an important part in the development of this relationship throughout Austen's text. Many of the scenes where Elizabeth judges Darcy as pompous or arrogant occur indoors. Her first meeting with Darcy takes place in a crowded public 
ballroom. Many of their interactions from that point forward occur in drawing rooms, dining rooms, and sitting rooms. These crowded, close quarters do much to shape Elizabeth's perceptions of Darcy, both as a gentleman of considerable wealth and as an eighteenth-century land owner. Elizabeth bases her understanding of Darcy in part on this indoor environment, which persists for the first half of the text. According to Mary Chan, "in Pride and Prejudice, space is used to characterize individuals and households," (2). Not until much later in the text does she come to experience Darcy in an outdoor environment.

The enclosed spaces of the rooms allow for privacy. This is ironic, in that these rooms are usually occupied by groups of people gathered together for a party. Yet the indoor spaces are divided in such a way that individual conversations can coexist peacefully, each unaware of the other across the span of a given room. In this sense, Elizabeth can both converse with Darcy personally and watch him enter into conversations with others. By observing his interactions in these indoor spaces, she forms her judgments.

One such opportunity to observe comes to Elizabeth during her time at Netherfield, keeping her sick sister Jane company as she recovers from her illness. Elizabeth spends time in the drawing room with the Netherfield party, passing the time in discussion with Mr. Darcy and Caroline Bingley. During this discussion Elizabeth begins to harden herself toward Mr. Darcy, finding in him a strict pride in his superiority of wealth and family name.

Miss Bingley invites Elizabeth to walk around the room with her. Elizabeth participates in the discussion sparingly at first, allowing herself the room and fresh vantage point from which to observe the lady's interactions with Mr. Darcy. This walk differs dramatically from Elizabeth's solitary trek to the estate. On the arm of Miss 
Bingley, Elizabeth takes the room by turns, matching her pace to the intentions of her companion.

As the women walk around the room, Darcy further exposes himself to the protagonist, speaking plainly about his own pride:

pride — where there is a real superiority of mind—pride will be always under good regulation...I have faults enough, but they are not, I hope, of understanding. My temper I dare not vouch for. It is, I believe too little yielding; certainly too little for the convenience of the world. I cannot forget the follies and vices of other so soon as I ought, nor their offenses against myself. My feelings are not puffed about with every attempt to move them. My temper would perhaps be called resentful. My good opinion once lost is lost forever. (48-49)

Darcy's words about himself are honest and true to his character. Yet they repulse Elizabeth, sending her further from him both socially and emotionally. These pieces, selfsupplied, when added to those she has already acquired through observation and mutual acquaintances, add further dislike to the puzzle that Darcy's character represents to her. The indoor spaces, crowded with people, reveal to Elizabeth the negatives of Darcy's character. Up to this point, the only evidence of his character-including his own words and observations about himself-present Darcy as a cold and conceited man, too proud for his own good.

Further proof occurs at the Netherfield Ball, which takes place shortly before Elizabeth is separated from Darcy for a time. At this ball, Elizabeth confesses to him while the couple dances that she is "trying to make out [his character]" with "such different accounts of you as puzzle me exceedingly," (81). Here again the space works against Darcy, offering Elizabeth only the views of him that support the words of others. 
Her environment, teeming with people and enclosed by layers of constructed walls, shapes her understanding of the characters in her world.

This indoor version of Elizabeth during the ball starkly contrasts with the Elizabeth who breaks all the social rules to walk alone across muddy fields, entering the boundaries of Netherfield energized and euphoric. Elizabeth's environment changes everything. This point is most strongly felt when Darcy shocks Elizabeth by proposing marriage to her while both are coincidentally on a visit to the estate of Rosings Park. This proposal, and its ensuing letter of explanation, change Elizabeth's environment, and by doing so confuse the opinions she considers fixed and true. Austen is demonstrating through both characters the error of relying only on aesthetics and first impressions to make judgments, a demonstration that will later prove central to the novel.

Darcy's proposal takes place in the sitting room of the parsonage that Charlotte shares with her new husband, Elizabeth's cousin Mr. Collins. Mr. Darcy enters the sitting room unexpectedly on a morning when Elizabeth is alone. Unable to contain himself within the space of the room, Darcy bursts forth with his proposal. The narrator details that Elizabeth "was at first sorry for the pain he was to receive; till, roused to resentment by his subsequent language, she lost all compassion in anger," (162). The words with which she actually rejects the gentleman, however, reveal her feelings towards Darcy: I have every reason in the world to think ill of you. No motive can excuse the unjust and ungenerous part you acted...From the very beginning, from the first moment, I may almost say, of my acquaintance with you, your manners impressing me with the fullest belief of your arrogance, your conceit, and your selfish disdain of the feelings of others, were such as to form that groundwork of disapprobation on which succeeding events have built so immovable a dislike; and I had not known you a month 
before I felt that you were the last man in the world whom I could be prevailed on to marry. $(163,165)$

The narrator then describes how, after hearing these final words, Darcy "hastily left the room, and Elizabeth heard him the next moment open the front door and quit the house," (165).

The moment of abrupt departure within the confines of a small parlor marks the climax of Elizabeth's mistaken judgments. In this enclosed space, Elizabeth shares with Darcy her complete understanding of his character, an understanding derived from experiences taking place in equally confined, indoor rooms. Upon hearing the strength of her convictions about his character, Darcy "quits the room" in haste, needing to remove himself from indoors to the outside landscape. This shift from the space of a room to the extensive space of the rambling outdoors begins to change Elizabeth's understanding because he leaves the house to write her an illuminating letter.

\section{The Tree Grove: The Outdoor Environment Changes Everything}

In the tree grove at Rosings Park, Elizabeth's carefully assembled character sketch of Darcy begins to crumble. After observing that "everyday was adding to the verdure of the early trees" around her, Elizabeth finds Mr. Darcy walking along the grove of Rosings Park, where he has been wandering in the hopes of meeting with her (167). Darcy is seeking Elizabeth in a more open and extensive space, also more private than those spaces where they had formerly been used to seeing each other. The intimacy of the quiet grove allows Darcy to explain, in the form of a letter, his involvement in the novel's events up till the moment of his proposal.

This letter changes everything for Elizabeth. Its contents make her realize her mistake in judging Darcy as no more than a conceited property owner concerned with 
his selfish agenda. As she reads his words, Elizabeth "grew absolutely ashamed of herself. Of neither Darcy nor Wickham could she think without feeling that she had been blind, partial, prejudiced, absurd," (177). Her emotions reveal that the environment in which she has formed her opinions of Darcy allowed her to be taken in by the wrongful words of others, primarily Wickham. The enclosed space of living rooms, ballrooms and parlors have allowed Elizabeth to likewise close off her mind, guided by the gossip of the indoor realm. Elizabeth, who always prides herself on being impartially discerning, has fallen into a serious social trap. The time she spends alone wandering around the estate, specifically along the lane that borders the park with a grove of trees, finally frees her mind of the opinions and ideas of others. She wholeheartedly repents of her previous behavior, now understanding the falseness of the words of Wickham and others in Hertfordshire society.

At this point Elizabeth's now open mind can begin to see Darcy as a different sort of creature; a man who up to this point has "never, in the whole course of their acquaintance...[done] anything that betrayed him to be unprincipled or unjust- anything that spoke him of irreligious or immoral habits," (177). Her new environment gives Elizabeth a chance to change her opinions, free of any social noise that could obstruct her thoughts and cloud her feelings. This fresh, quiet moment of deliberation opens a path for Elizabeth, so that she can begin to see Darcy as a responsible steward rather than as an example of the emerging, more selfish class of private landowner.

This new image of Darcy is set in stone when the protagonist sets eyes on Pemberley for the first time and witnesses his altered behavior for herself. As she approaches the property, Elizabeth

saw and admired every remarkable spot and point of view...the eye was instantly caught by Pemberley House, situated on the opposite side of a 
valley, into which the road with some abruptness wound. It was a large, handsome stone building, standing well on rising ground, and backed by a ridge of high woody hills; and in front, a stream of some natural importance was swelled into greater, but without any artificial appearance. Its banks were neither formal, nor falsely adorned...She had never seen a place for which nature had done more, or where natural beauty had been so little counteracted by an awkward taste. (206) Austen crafts her description of Pemberley to include specific details about how nature organically folds into the property around the main house. The building itself is a strong stone that blends into its environment. Any visible man-made changes have been carefully executed so that the property keeps as many of its natural enhancements as possible. There is nothing artificial or false in the landscape garden of this estate.

Critics often debate whether her first glimpse of Pemberley changes Elizabeth's mind about its owner. According to Mary Chan, "Austen's famous description of Pemberley makes readers reconsider Darcy because we assume that a man with such a well-appointed house cannot be entirely disagreeable" (2). Elizabeth's reaction to Darcy's letter, however, only proves that her feelings are already being thrown into confusion once she allows herself time to reconsider events with his side of the story in hand. The change in her environment causes this shift, giving her freedom to understand her world without prying social gossip.

Rosemary Bodenheimer deliberates how Elizabeth's strong reaction to the estate proves "Pemberley is a 'prospect' that looks good in any frame. The multiplicity of views, all fine, contributes to the general strategy of piling up positive impressions, and of superseding the earlier rigid and partial assessment of Darcy," (610). The vision of Pemberley reveals a new depth to Darcy's character that the protagonist has not seen 
before. The formal but not "falsely adorned" banks of the river and the slope of the approach to the house all reflect Elizabeth's changing view of Darcy himself.

Once Darcy is seen in a new light, one may wonder if the view of Pemberley evokes a reaction from Elizabeth that is genuinely coming from her environment. Ecocritic Robert Kern discusses this very idea, surmising that "the language [of Austen's description of Pemberley] hints of what one imagines to have been some strenuous efforts of earthmoving and landscaping, and Elizabeth seems all but conscious of the extent to which what she sees here is a calculated illusion... On the one hand, the place is naturally beautiful; but on the other, it has been altered," (264-265). Kern's argument raises the question whether Elizabeth is looking at the environment of the landscape as it naturally occurs, or an altered perception of that landscape created by the aesthetic ideals and opinions of the eighteenth century notion of the picturesque.

It is clear that Darcy has made improvements to the property since inheriting it from his late father. This topic comes up at Netherfield, where Caroline Bingley comments on Darcy's additions to the library of Pemberley. Yet these changes have not compromised the integrity and heritage of the estate. They have rather enhanced what was already present. Darcy's improvements, then, are a positive change to the estate. Like Fanny and Edmund in Mansfield Park, Darcy's style of improvement is simple and in keeping with the natural environment itself. He does not make dramatic changes to the landscape park, but demonstrates "a preservationist approach, one which seeks to maintain the environment in its own, unaltered state," (Kern 266). Unlike Rushworth and the Crawfords in Mansfield Park, Darcy works with nature, rather than against it, as he forms his plans for Pemberley.

Elizabeth's view of Pemberley, then, is admittedly of an altered place. The alterations, however, work with nature, supporting the original design of the inherited 
estate. The trees on the estate demonstrate this preservationist attitude on the part of the landowner, standing tall in the face of other common emerging garden features of the eighteenth century. They continue to stand as an emblem throughout the rest of the text, supporting the idea of responsible stewardship on Darcy's part. Where Rushworth would happily cut away tree avenues to open up a view, Darcy rather works with the trees already there, maintaining them as key features on the property that line the stream. Pemberley remains a healthy estate, with its "abundance of timber" and natural beauty (Duckworth 39).

The housekeeper's praise completes the evolution of Elizabeth's picture of Darcy as a steward. When speaking on the subject of Mr. Darcy's behavior as a landlord and master, the housekeeper Mrs. Reynolds describes Darcy in a way that both surprises and impresses Elizabeth and her relatives:

He is the best landlord and the best master that ever lived. Not like the wild men now-a-days who think of nothing but themselves. There is not one of his tenants or servants but what will give him a good name. Some people call him proud; but I am sure I never saw anything of it. To my fancy, it is only because he does not rattle away like other young men. (210)

Elizabeth acknowledges the housekeeper's praise as the highest recommendation Darcy can have as a landlord, for "what praise is more valuable than the praise of an intelligent servant?" (211). Mrs. Reynolds' description of him only further disproves Elizabeth's first assumptions about Darcy. Mrs. Reynolds' words awaken a strong response in her "that he was not a good-tempered man had been her firmest opinion," (209). At this point Elizabeth completely changes her mind about Darcy and comes to 
accept her new feelings for him, both as a shining example of responsible steward and as a future husband with a mind and set of values equal to her own.

\section{"I Know No Such Thing of the Practice of Elegant Females"}

Elizabeth then takes this question of responsibility into her own hands at the novel's end when Lady Catherine confronts her in her own grove at home. Experienced with other females, however, these gardens offer Elizabeth a more difficult taste of independence than her solitary excursions. This struggle for freedom emerges most strongly in Elizabeth's encounter with the Right Honorable Lady Catherine de Bourgh, wealthy widow and sole owner of the country residence of Rosings Park.

Elizabeth's first experience of Lady Catherine occurs as a guest at Rosings Park where, although she is expected to feel awed by the extensive grounds and shaded garden walkways of her Ladyship, she manages to retain her strong sense of self-worth. In her article "Women Create Gardens in Male Landscapes," Susan Bell suggests that only women in positions of greatness or independent wealth -such as Lady Catherinechose to harness the power of landscape gardens as grand, political statements (480). Lady Catherine's expansive grounds have no effect on Elizabeth, despite this gesture of wealth and authority. Austen says of her first impressions of the countryside estate: they had a pleasant walk... across the park. Every park has its beauty and its prospects; and Elizabeth saw much to be pleased with, though she could not be in raptures as Mr. Collins expected the scene to inspire...the mere stateliness of money and rank she thought she could witness without trepidation (138).

Though Elizabeth does pass the chief time of her visit in this portion of the grounds, she never comes to treat this area of the property as a shrine to wealth and 
privileged power. Instead, she spends the majority of her time in the garden walking in quiet reflection and self-study. The garden ironically becomes a place of respite for Elizabeth, an escape she can turn to when she wishes to elude Lady Catherine or the other guests of Rosings Park. Thus from the beginning of their relationship, Elizabeth's actions strive to convert the dowager's misconceived notions of power and wealth to suit the heroine's own simple value system.

By the end of the novel, Elizabeth's final confrontation with the dowager manifests this tendency. The heroine uses the garden environment to assert her values and self-worth. Her Ladyship takes the entire Bennet family by surprise, arriving in haste in the early morning, at a time "too early...for visitors," (299). Rather than explain the reason for her visit within the Bennet home, Lady Catherine invites Elizabeth to take a walk with her outside, alone and free of any interference from Elizabeth's curious family. Catherine's breach in decorum is the first sign of her Ladyship's belief that Longbourn estate acts as an extension of Rosings Park, allowing Lady Catherine to practice the same rank and privilege she experiences at her own residence.

Up to this point, Lady Catherine has dictated the terms of her rushed and unexpected visit by coming unannounced and trespassing on the courtesy and kindness of the Bennet family. She has refused drink or any other refreshment, and has rudely judged the value of the rooms within the home. Her precedence in a normal social hierarchy dictates the acceptability of this type of behavior, though rude, because of her high place within that society. She says of the Bennet garden, "there seemed to be a prettyish sort of a little wilderness on one side of your lawn. I should be glad to take a turn in it, if you will favor me with your company," (300). The uncultivated Longbourn pleasure garden, in other words, cannot compete with her ladyship's powerfully landscaped grounds and beautiful park lanes. Mrs. Bennet again tries hosting her 
Ladyship, entreating that Elizabeth show the dowager the grounds. Though Elizabeth obeys, she does not share in Mrs. Bennet's show of kindness to their grand visitor.

The question remains as to why Lady Catherine feels the need to move the conversation outdoors. Longbourn, "an estate of two thousand a year," is a home whose prestige cannot compete with that of her own home at Rosings Park (22). Despite this, Mrs. Bennet entreats Elizabeth: "show her ladyship about the different walks. I think she will be pleased with the hermitage," hoping the Longbourn grounds please the dowager (300). Though Austen crafts no exact description of the estate, Jane and Elizabeth reportedly share secrets in the property's "shrubbery" or copse, a necessary garden feature in any respectable gentleman's home (44). She and Lady Catherine "proceeded in silence along the gravel walk that led to the copse," for Elizabeth "was determined to make no effort for conversation with a woman who was now more than usually insolent and disagreeable" (301). The gravel walk, made up of small hard stones, anticipates Elizabeth's determination and commitment. Mrs. Bennet anxiously hopes Lady Catherine recognizes that modest Longbourn keeps up with fashionable garden trends.

The move outdoors, then, seems to be the effort of Lady Catherine to establish some sort of footing for herself within the foreign territory of the Longbourn estate. While the inferior house is unfamiliar, peopled by an unfamiliar family, the gardens just outside are organized into walks and pathways Lady Catherine can relate to, though on a smaller scale than Rosings Park. The shift from the indoor to the outdoor space allows Lady Catherine the chance, then, to reassert privately her position of absolute superiority over Elizabeth, even outside the confines of normal social hierarchy.

As the women move into the garden, the heroine's revelation of the overwhelming strength of her values and beliefs subverts Lady Catherine's plan. Once again, the empty image of superiority that her ladyship sets before her does not sway 
Elizabeth. Her independence and strength of character, though shaken by the surprise of the dowager's visit and unusual behavior, return to her once she is surrounded by the growing plants and pathways of the household copse. When Lady Catherine begins to assault Elizabeth verbally about Mr. Darcy's discovered affection for the heroine, Elizabeth responds by lashing back verbally at the dowager, something that Elizabeth has never openly dared to do until this moment.

Elizabeth's power to subvert normal social standards in this space has to do with the topography of improvement. Her proximity to the cultivated natural areas of her home bring Elizabeth back to that same state as in the beginning of the novel where she walks "jumping" and "springing" to Netherfield. Here, Elizabeth harnesses that emotional freedom that comes to her within the garden, using it to jump and spring through Lady Catherine's thinly veiled insults. Only once as they are walking along the gravel walkway with the copse in sight that Elizabeth does think to herself that she "was determined to make no effort for conversation with a woman who was now more than usually insolent and disagreeable," (301). That rebellious, subversive spirit which encourages the heroine to convert the underlying meaning and use of the Rosings gardens now gives her the strength to emphasize verbally her self-worth and superiority, creating a new private hierarchy between herself and the dowager.

Once her Ladyship begins to speak, Elizabeth obstinately refuses to provide her with any of the answers she has traveled so far to seek, remaining firm in her denial of Lady Catherine's right to information, especially given the Lady's behavior. Elizabeth's strength and stubbornness anger Lady Catherine, who seeks again and again to put Elizabeth in her place forcibly during the length of the conversation. She says at the beginning of her angry speech: "Miss Bennet...you ought to know, that I am not to be trifled with," (301). After this first attempt to intimidate Elizabeth, Lady Catherine then 
proceeds to belittle her in the hopes that this will remind the heroine of her inferior place: "I was told...that you Miss Elizabeth Bennet would... be soon ...united to my nephew... Though I know it must be scandalous falsehood; though I would not injure him so much as to suppose the truth of it possible," (301). When surprised or angry, the dowager turns to her social rank to resolve the distasteful situation and once again make her wishes become the reality.

As the conversation advances and Lady Catherine recognizes her barbs are not having their desired effect, she changes her position, telling Elizabeth "let us sit down" (303). Sitting down in the shrubbery begins to put the dowager in a posture of defeat. Elizabeth takes advantage of this weakness, and responds to the dowager's strong assault with her own strength of character. She does not allow herself to be bullied here, in her own garden. Her language turns Lady Catherine's assault against her, bringing to light its fraudulent, contrary nature. She says,

You are not entitled to know [my concerns]; nor will such behavior as this ever induce me to be explicit... I am not to be intimidated into anything so wholly unreasonable...You have widely mistaken my character if you think I can be worked on by such persuasions...I am only resolved to act in that manner which will, in my own opinion, constitute my happiness, without reference to you, or to any person so wholly unconnected to me... Neither duty, nor honor, nor gratitude... have any possible claim on me, in the present instance. No principal of either, would be violated by my marriage with Mr. Darcy. (303-305)

Elizabeth, by planting her foot firmly in the soil of her own value system, shuts down Lady Catherine's grandiloquent, empty display of power. The dowager's landscape 
garden on the grounds of Rosings Park portrays her wealth as a member of a superior social class. Yet, once she steps beyond it into Elizabeth's own simple, virtuous plot, the heroine can strip the dowager of her empty power and reveal the Lady's deficiency of any true class within the context of character. Elizabeth's garden, though significantly smaller and less powerfully organized, honestly reflects her heartfelt passion and virtue. Surrounded by its sincere, "prettyish" features, confirms Elizabeth's conviction of her superiority of character to that of Lady Catherine. Though the dowager strives to reinstate her social leadership, her wealth cannot take root in this particular natural area where it has no place or purpose in this cultivated environment, and so she breaks down in the face of Elizabeth's power. She rises from her seat in the shrubbery and leaves Longbourn rudely without returning to the house.

Ultimately, Elizabeth is the clear victor of this confrontation with social prejudice and authority. Surrounded and supported by the context of the natural world, she can stand against the social prejudices which Lady Catherine strives to use against her. Her firm sense of self-worth, understood within the symbolic nature of the garden, allows the heroine to surpass the normal understanding of authority and assume a superior position within the relationship between herself and Lady Catherine.

She stands up to the dowager, knocking down Lady Catherine's notions of keeping her family as private and enclosed as her land at Rosings (by desiring her daughter and Darcy, as wealthy cousins, should marry). Elizabeth breaks this enclosure with her very intrusion into Darcy's heart, and demonstrates through her words that she is ready for a share in Darcy's stewardship.

Mansfield Park continues Austen's pattern of championing a preference for responsible stewardship over self-serving ownership. Though the majority of Austen's novels adopt the motif of estate improvements to some degree, this text in particular 
focuses most strongly on the subject. Throughout the novel, Fanny Price proves herself a remarkable woman protagonist through her fervent constancy. Where other Austen woman protagonists must work to improve themselves and make up for past mistakes before they can morally deserve a part in their husband's stewardship, Fanny is deserving of this fate from her very humble beginnings. This characteristic makes Fanny and her novel, Mansfield Park, an excellent point of exploration into Austen's notions about stewardship and improvement within the context of the newly emerging generation of eighteenth-century landowners. 


\section{Mansfield Park: Strong Statements on Stewardship}

"Grove nods at Grove/

Each alley has its brother."

-Epistles to Several Persons, Epistle IV, Alexander Pope

In Mansfield Park, Fanny Price observes the people around her as they plan weddings and entertain themselves with discussions about their property. The marriage of Fanny's cousin, Maria Bertram, to Mr. Rushworth of Sotherton Court results in several discussions about the particulars and value of improving an estate's park grounds. While Rushworth plans to improve his estate to demonstrate his wealth and high place in that county's society, Lady Bertram and Mary Crawford privilege the modern shrubbery as a frivolous, private pleasure garden. These characters all emphasize private pleasure over their responsibility to their community.

Fanny, on the other hand, decries the destruction of the tree avenue at Sotherton- a necessary byproduct of Rushworth's improvements. Fanny's respect for the historical value of the trees validates her understanding of stewardship as a priority in estate planning. In addition, her desire to see Sotherton's chapel restored to its former

glory as a means of bringing the estate community together manifests her respect for stewardship. Fanny recognizes and privileges traditional views of culture and ownership.

\section{Sotherton Court: "A Good Spot for Fault-Finding"}

Having just visited the recently improved estate of a friend, a Mr. Smith, Rushworth is full of the subject from his very entrance into the text. He claims that after the improvements he has witnessed on Mr. Smith's property, Sotherton looks like "quite a dismal old 
prison" by comparison (53). The transformation of Smith's estate transforms how Rushworth sees his own property as ripe for improvement.

The narrator reveals Rushworth's character at this entrance, as well as the nature of the alliance between him and Maria Bertram. He or she relates how "the subject [of improvements to Sotherton] had been handled in the drawing room; it was revived in the dining-parlor...Miss Bertram's attention and opinion was evidently his chief aim" (53). Rushworth hopes to entice Maria to respond with the topic of improvement to her future home. The size and reputation of Sotherton Court is the most attractive feature attached to Rushworth, a fact that he is acutely aware of in his interactions with Maria. The gentleman's tactic works, though not quite to his advantage, as the lady's "deportment showed rather conscious superiority than any solicitude to oblige him" (53). Maria is not insensible to her lack of true attachment to her fiancé. She has no romantic notions about this marriage, only tolerating Rushworth's conversation as "the mention of Sotherton Court, and the ideas attached to it, gave her a feeling of complacency, which prevented her from being very ungracious" (53). In this relationship, a marriage of convenience for both parties, the substantial land acts as an inducement to marry an otherwise intolerable suitor.

Rushworth's actions in pursuing the topic so doggedly demonstrate his vanity and pride in his family's historically established position as estate owners. Maria's aunt, Mrs. Norris, responds to the gentleman's introduction of Sotherton, describing the estate as "the noblest old place in the world" (53). She, like Rushworth, defines the estate's worth by its age and the landowning family's established connections to nobility. Sotherton Court, a calling card, announces Rushworth's wealth and power to the world. Rushworth claims, however, that he "never saw a place that wanted so much improvement...it is so forlorn" (53). The very features which make the estate attractive to 
both Maria and Mrs. Norris act against the favor of the property in his eyes, creating a problem for Rushworth's pride.

Rushworth must build on his family's pre-established reputation in the county to prove his place and worth in that society. He achieves this by keeping up with new standards and changing tastes. He follows the steps of the current generation of inheriting landowners, making something new out of the old park. He solves this simply: improve his grounds in the same modern fashion as Mr. Smith.

The group takes up the question of how best to improve the estate over the next several chapters. No one, however, doubts who should make those improvements. Maria Bertram tells her fiancé that his "best friend upon such an occasion...would be Mr. Repton" (54). Rushworth agrees immediately with her, identifying from the beginning of the discussion Humphrey Repton as the only man capable of taking on the improvements at Sotherton Court.

Repton, one of the leading landscape designers in England during Austen's lifetime, worked to bring new color into eighteenth-century parks (Quaintance 365). Hobhouse notes that

Repton was the most influential landscape gardener- he was the first to use this title- to bring back flowers into parts of the great gardens. He incorporated them in enclosed areas which he might advise planting a rosary (as he did in Ashridge) or gardens specifically for American or Chinese plants such as hydrangeas. (Hobhouse 202)

Writing five books on the subject of landscape gardening and design within a span of twenty years, he worked on over four hundred estates, ensuring that these landowners would "feel that the view from their doorway was more like what it ought to be" (Quaintance 365-366). Repton achieved this by including sketches in his notebooks of 
the original estate grounds and sketches of their expected transformation once his ideas took physical shape and presence in the landscape (Quaintance 368-369).

The decision to hire Repton so immediately for this enterprise, with so many landscape architects available during the temporal setting of the novel, illustrates Repton's skill and reputation. Repton's name in this discussion between Austen's characters reveals his cultural importance. His reputation as a leading landscape architect necessitates Rushworth's hiring him for the improvement project. The knowledge that Mr. Smith, an inferior rival homeowner, also hired Repton finalizes Rushworth's decision. Rushworth cannot fall behind the times.

With Repton's superiority as a landscape designer established, the question of how to pay for his work at Sotherton soon enters the characters' discussion. Rushworth begins the topic himself, making mention of Repton's fee: "As he has done so well by Smith, I think I had better have him at once. His terms are five guineas a day" (54). The gentleman has no scruple with casually mentioning the price of these improvements. He waves the cost off as a mere trifle, a necessary part of keeping up with new styles and ideas for a wealthy, modern family.

\section{"One Likes to Get Out Into a Shrubbery"}

Austen's descriptions of Mr. Rushworth's character, as well as his part in the discussions, classify him as a member of the emerging generation of landowners whom Cecilia Easton describes as choosing privacy over social responsibility (Easton 74).

Duckworth and Bate both support this image of the new generation. All three critics, however, neglect to explore the willingness of Austen's woman protagonists to participate actively in the landownership of their spouses and families. This willingness extends even in the face of their gender and the social understandings of land heritage 
that impede their desire to assume a more active social role. Despite the politics and laws surrounding gender, these women have opinions. More surprisingly, they actively offer them up.

Several women characters in the text voice the desire for participation, though each may claim a different understanding as to what that participation should entail. Mrs. Norris, the first woman to enter the conversation of improvement, expresses her opinion that "the expense [of improvements] need not be any impediment," for "such a place as Sotherton Court deserves everything that taste and money can do," as it has "space to work upon" and "grounds that will well reward" (54). For Mrs. Norris, the expansive grounds and the potential of the property to yield riches to future generations make it worth every penny that Rushworth spends on improving it in the present. In keeping with the mentality of the period, the landscape park is meant less for enjoyment than for building up for future generations, increasing the power and wealth of the family over time. These comments also further reveal a different side of Mrs. Norris, usually so stingy, as a person very happy to pass the time by spending other people's ready money.

As much as this passage reveals about Mrs. Norris, it also supplies insight into her understanding of the role of a landowner. Once she dispenses with her encouragements for improvement to Rushworth, she recounts her own adventures endeavoring to improve the parsonage at Mansfield Park, and her current state as a widowed property owner. She says,

If I had anything within the fiftieth part of the size of Sotherton, I should be always planting and improving, for naturally I am excessively fond of it. It would be too ridiculous for me to attempt anything where I am now, with 
my little half acre...But if I had more room, I should take a prodigious delight in improving and planting. (54)

The size of the estate decides whether it merits the attention of a landscape designer like Mr. Repton. The larger the estate, the more its improvement denotes effective ownership. With her significantly smaller income, Mrs. Norris does not share the same luxuries as a male property owner, and so cannot enjoy ownership to the same degree that Rushworth can.

Yet her comments are also deceiving. Her logic dictates that only the wealthy can enjoy the luxury of spending their money on crafting an enjoyable outdoor space; in fact, according to Mrs. Norris, wealth and size demand that an estate be showcased and spectacular. The larger the estate, the greater the owner's responsibility to care for employees and staff. Exclusively superficial improvement, then, only augments the vanity of the owner and causes him to go against this duty. Improvement in this sense is strictly about holding dominance over the land, rather than acting as its steward.

Though each character canvasses the topic to achieve very different goals, both Rushworth and Norris share a common understanding of the participation of the landowner in the actual process of improvement as it moves from the planning phase to execution. Mrs. Norris plans improvements to Sotherton with relative ease as the money and duty in question are removed from her. She shapes and encourages the idea while having no share in the expense and responsibility of the enterprise itself. Rushworth likewise removes himself from the equation, procuring "some good friend" (a landscape architect such as Repton) to plan the design of the park on his behalf (54). Any changes made to Sotherton result from the genius (or folly) of someone else. Once again, the park is treated as an object manipulated for private taste. Improvement allows the owner 
to escape the responsibility of changes to the estate, while taking the credit should those changes prove socially positive.

Mary Crawford, a visitor at Mansfield Park's parsonage, considers herself within this same school of thought. She draws Maria's brother Edmund into the discussion by recounting her own limited experiences with countryside improvements. She says, "had I a place in the country, I should be most thankful to any Mr. Repton who would undertake it, and give me as much beauty as he could for my money; and I should never look at it, till it was complete... but it all must be done without my care" (58). Miss Crawford, like Mrs. Norris, sees improvements as a means to achieve a property complete with everything nature ought to have. Both women and Mr. Rushworth seek to improve land as a product, marketed by word of mouth and sold to society as an ideal image of a wealthy eighteenth-century landowner.

The chief improvement to a landscape park for women like Mary during this shift in landscape tastes consisted of the addition of a shrubbery to the property. Mary expresses the desire to have "everything as complete as possible in the country, shrubberies and flower gardens, and rustic seats innumerable" (58). ${ }^{10}$ Women needed the flowers and shrubs in a garden and areas to rest in the shade. While women of this class may "occasionally express an interest in the latest ideas of landscape planning, their passion was [typically] for flowers and shrubs" (Bell 477). Lady Bertram, a character who seldom speaks throughout the text, seconds this priority. Yet she includes herself in the conversation, troubling herself to give Rushworth advice that he must "... have a very pretty shrubbery" as "one likes to get out into a shrubbery in fine weather" (56).

\footnotetext{
${ }^{10}$ Lady Catherine de Bourgh and Elizabeth Bennet sit in such a rustic seat in Pride \& Prejudice, discussing the rumor of Elizabeth's potential marriage to Mr. Darcy.
} 
The English shrubbery emerges during the eighteenth-century as a new, distinctive component of the picturesque pleasure ground (Batey 43). They were found "extensively in spa gardens, the early public parks and communal gardens... as well as in private pleasure grounds" (Batey 43). Their popularity and fixed nature within English garden culture during the period appears in their inclusion in all manner of English gardens.

As the seventeenth century came to a close, walls began to disappear from landscape garden design, and the countryside instead "merged with the landscape by means of the ha-ha" (Griswold 85). The huge numbers of North American introductions that could grow successfully outdoors in Britain created pressure to include them somehow in the fashionable garden. Larger American bushes and smaller trees went to the "shrubbery," an entirely new part of the garden (Griswold 86). These exciting new 'Americans', were used to introduce a 'wilder' note to what had been formal French-style wildernesses in which winding paths now replaced straight alignments...the shrubbery emerged as a planting style distinct from the more orderly wilderness of the French taste. (Hobhouse 200)

Griswold provides further information about the evolution of the wilderness into the shrubbery:

The eighteenth-century shrubbery evolved from areas in earlier formal gardens called "wildernesses," where parts were cut through plantations of tall trees fenced by high clipped hedges... Such paths, at first straight and often in radical designs like those in forested hunting parks, later wound in serpentine, mazelike patterns. Gradually, high hedges gave way to low edgings, and tall trees were under-planted with flowering shrubs. 
When trees were finally relegated to the back row of these plantings, when sun that is took over from shade, the shrubbery was born. (Griswold 88)

With this birth of the shrubbery, new flowers were introduced to add color to the grounds, their layout seemingly natural and wild. These flowers could include "stocks, double and single pinks, pleasant eyes and double rocket, Sweet Williams, Fetherfew, Roses, India pinks of different colors, honeysuckles, larkspur, some asters, some auriculas, carnations, and some nasturtiums'" (Hobhouse 201). The newer varieties were pleasing to the eye and added a fresh look to the new garden feature.

The purpose of these shrubberies was twofold: to serve as both an ornamental area of the garden and as a way to break "up spaces in public gardens... to give walkers more privacy" (Batey 43). The characters of Mansfield Park who enjoy this space and feel it necessary to a renovated landscape garden privilege this idea of private tastes over community needs. Both Mary and Lady Bertram express the importance of having such a space in which to experience beauty and personal pleasure. That Lady Bertram takes the time to insert herself into the conversation, something that happens only a few times within the whole of the text, shows the importance she as the wife of a significantly wealthy property owner attaches to the shrubbery.

A shrubbery, with its functionality as a space set aside entirely for personal pleasure, serves no true purpose in a traditional English countryside community. Its creation and adoption into the daily life of women in the eighteenth-century effectively demonstrates the transformation of landownership from a public realm of toil to a private one of pleasure. The shrubbery, then, comes to represent metaphorically this group of women in Austen's novels who identify with the new modes of landscape design and 
landownership. Those who favor it as a necessary part of an estate identify, through this opinion, their definition of land ownership as personal enjoyment and private creation.

\section{Fanny and Stewardship}

These views of land ownership, though prevalent among many of the women in the novel, do not stand alone in the text. Another definition of a landowner emerges during the conversation among the assembled party at Mansfield. While Rushworth and Mrs. Norris feel all the advantages of hiring an improver who can add modern style and taste to an estate in want of a new design, Fanny and Edmund express a shared desire to see improvements take shape by their own hand. In response to Mary Crawford's opinion of improvements themselves as a nuisance, Fanny remarks, "It would be delightful to me to see the progress of it all" (58). This includes both the design of park features and personally overseeing the physical labor involved in executing those plans. Where Mary wishes everything to be done for her in her absence, Fanny desires to oversee the changes to the property, assisting where possible to plan and implement positive change to the grounds. She desires direct influence and participation.

When Fanny demonstrates her passion for the grounds of a country estate, the differences in these women emerge. The woman protagonist declares this passion herself when Rushworth mentions some of the steps he has already considered to improve his property. He explains,

There have been two or three fine old trees cut down that grew too near the house, and it opens the prospect amazingly, which makes me think that Repton, or any body of that sort, would certainly have the avenue at Sotherton down; the avenue that leads from the west front to the top of the hill. (56) 
Improvements to an estate must sometimes include cutting down avenues to make way for a lovely view of the rest of the park grounds.

Trees carry an important place in the history of English literature. According to Andrew Garner, "trees are identified with humans, and admired for their great proportions, old age, potency and self-regenerating energy... [it is] as though trees were a large metaphoric bucket able to contain a broad selection of eclectic values" (Garner 87-88). Trees have long stood as emblems for various concepts and ideas throughout English literary history, particularly as emblems of seeking a shared identity or as emblems of "organic growth" (Duckworth, "Grounds for Being" 40). Austen's part in this literary heritage is easy to discern; as Bate tells us, "her allegiance was to the rough old walnut tree," a native English tree (258). In Austen's texts, "the presence of trees betokens value" (Duckworth 40). Their presence demonstrates a healthy estate.

Where trees serve as a sign of a property's fruitful production and moral prosperity, the cutting down of trees "suggest[s] a break with the past," and serves "as a sign of the present owner's corrupted values" (Duckworth 40). Rushworth's cutting down of an avenue, then, clearly indicates his "corrupted values" as a landowner. This particular passage where he relates the cutting down of "two or three fine old trees" sparks many arguments among critics as to Austen's opinion of Repton's style of improvement. Though some critics feel her abuse of him in the novel shows disapproval of his work, others, e.g. Richard Quaintance, argue that Repton plays a scapegoat, allowing Austen to make a larger statement about improvements in general. In his 1806 book, Repton claims that "the change of fashion in gardening destroys the work of ages, when lofty avenues are cut down for no other reason but because they were planted in straight rows, according to the fashion of former times" (Quaintance 370). Hence, Repton opposed the removal of tree avenues to enclose a property for the sake of 
money when the landscape on its own could provide a range of interesting views and features to please the eye. He did, however, express the need to remove tree avenues when they blocked an interesting feature or funneled wind towards buildings. Even in these instances, however, he preferred thinning the avenue rather than cutting it down (Quaintance 372).

This part of the process of improvement strongly affects Fanny. She exclaims, "Cut down an avenue! What a pity! Does it not make you think of Cowper? 'Ye fallen avenues, once more I mourn your fate unmerited'...I should like to see Sotherton before it is cut down, to see the place as it is now, in its old state" (57). While the other women of the party dwell on the need for a shrubbery, Fanny experiences a loss for the cutting down of trees in Sotherton. While Mary and Lady Bertram privilege garden flowers and small shrubs, Fanny understands a greater priority in sparing the more ancient trees. Her sense of loss comes from a deep-rooted appreciation and respect for the history and heritage of landscape features that have the potential to last from generation to generation with good care. Like many of Austen's woman protagonists, Fanny delights in the natural world that surrounds her in its natural state. For Fanny, the value of the new style of landscaping does not equal the value of the trees that will be lost in the process.

The question of how the shrubbery and tree avenues differ stylistically from each other is an important question to ask for this analysis. According to author Kim Wilson, Garden designers thought it important to match the character of the path, the seats, and the plants with the wilder character of the wood walk. Consequently, probably fewer flowers would have been found in a 'wilderness' wood walk than in a shrubbery, though those considered appropriate to woodlands such as violets, primroses, and snowdrops 
might be allowed to grow scattered here and there in a natural fashion. (Wilson 35-36)

The shrubbery and avenues differ, then, in the particular atmosphere they intend for the person walking the paths. Hobhouse suggests that

nature improved and made pleasing to the eye could generate distinct feelings and sensations- became a further ingredient of landscaping. Gaiety, grandeur, tranquility and, above all, melancholy and 'sublimity' were all to be evoked by various devices such as breaking the lawns' edge with clumps of trees and turning canals into winding streams or placid lakes. (Hobhouse 196)

For this reason, the tree avenues represent a more traditional view of landownership in Austen's texts, espousing stewardship of the land over a desire to dominate it with private tastes. Fanny's admiration of tree avenues and groves, then, reveals her longing for consistent, responsible stewardship and the chance to participate actively in this stewardship.

\section{"Every Generation Has Its Improvements"}

Fanny's admiration motivates her to cherish the tree avenue of Sotherton Court as it naturally appears before the proposed estate improvements. The avenue is so central to Fanny's understanding of Sotherton that she spends an entire afternoon visit to the estate striving to reach it despite the setbacks that her fellow travelers create with their behavior.

Upon their entrance to the boundaries of the estate, Fanny briefly compliments the house along with her fellow travelers. She expresses impatience, however, to see the tree avenue and quickly asks Maria about this feature of the grounds: "Now, where is 
the avenue? The house fronts the east, I perceive. The avenue, therefore, must be at the back of it. Mr. Rushworth talked of the west front" (85). Her knowledge of the layout of Sotherton's grounds demonstrates that Fanny has already built up a picture of the avenue in her mind, and now wants to compare that picture to the reality unfolding before her.

As the group begins to wander the estate's grounds, Fanny begins to encounter obstacles before achieving her desired destination. As she walks, she falls into step with her cousin Edmund and Mary Crawford. Fanny's constitution, however, does not allow her to walk for great distances. She soon becomes fatigued and has to rest, choosing a bench that overlooks the ha-ha surrounding the park. Edmund and Mary express a desire to walk on, and despite Fanny's protest that she is refreshed, they leave the protagonist behind.

Sitting alone, Fanny wonders at being forgotten. Her constancy keeps her on the bench, sure that her cousin will soon return as promised. Yet time passes and she remains in view of the avenue, unable to access it. The arrival of Maria Bertram and Henry Crawford only augments her distance from the avenue, as they both wriggle through a gap by the gate and into the park rather than waiting for Mr. Rushworth to bring the key. Fanny feels the impropriety of their behavior. She tries to stay Maria's impulsive desire to free herself of the restraint afforded by the locked gate. Maria, however, continues to move through to the park, allowing herself the pleasure of being alone with Crawford, despite the potential scandal this dalliance could create for herself and her family. She further restrains Fanny from her goal by charging her with the task of informing Mr. Rushworth where he will find the couple upon his return with the missing gate key. Julia Bertram's arrival offers no reprieve for Fanny, as the young woman soon 
follows her sister's example, likewise sneaking through the gate alone rather than waiting for Rushworth's key to give her access to the park.

Fanny's final visitor during her vigil of the avenue from a distance is Rushworth himself, at last arriving with the forgotten gate key. Offended at his being left behind, he soon leaves Fanny to her own devices and goes in search of the missing couple, Maria and Crawford. Fanny can now at last achieve the avenue, free of any restraint. She rises to do so, and expects to find her cousin Edmund as she makes her way towards it. Her cousin and Mary return, impeding her progress. At last, Fanny realizes she will never reach her goal, as the couple relates how "they had been across a portion of the park and into the very avenue which Fanny had been hoping the whole morning to reach at last; and had been sitting down under one of the trees" (107). The protagonist feels general "disappointment and depression, as they prepared, by general agreement, to return to the house" (107).

Fanny, then, never reaches the avenue despite all of her longing and striving to achieve its shade. Mary Crawford instead reaches this garden feature on Edmund's arm. Yet Mary also prefers the shrubbery and the newer style of improvement which would soon call for the termination of the avenue. Thus, the character who least appreciates the space is the one to achieve it.

At the same time, Fanny's interest in the avenue may detract from the use of that avenue as a symbol of genuine feminine interest in stewardship because of Fanny's romanticizing. As Fanny moves about the main house of Sotherton, she falls into this same danger of seeming to play the romantic heroine, rather than a protagonist interested in the heritage and history of the property. Fanny's walk through Sotherton recalls Catherine Morland's tour of Northanger Abbey, or Marianne Dashwood's passion for dead leaves at Norland Park. 
Fanny, however, demonstrates a moral constancy in her appreciation to nature which sets her aside from these weaker and more romantic of Austen's woman protagonists. In the chapel of Sotherton, Fanny mourns that the current Rushworth family members have discontinued the practice of calling the entire household- maids, footmen, and family members- to prayer twice a day. She says,

It is a pity that the custom should have been discontinued. It was a valuable part of former times. There is something in a chapel and chaplain so much in character with a great house, with one's ideas of what such a household ought to be! A whole family assembling regularly for the purpose of prayer is fine! (89)

The chapel's state of disuse represents the same problem to Fanny as the cutting down of a tree avenue for a better view. In its heyday, the chapel strengthened the community, calling everyone to worship together as one. In the same vein, the tree avenue as a garden feature stood the test of time, measuring the family's heritage by the growth of its trees. To have the chapel services discontinued and the trees cut down marks a new path for land ownership that deviates from community and moves instead toward the privileging of the lord and master's pleasure.

Edmund recognizes this problem when Mary Crawford laughs at Fanny's belief that the chapel once added value to the community. She claims that the heads of family must have always been "inventing excuses themselves for staying away" (89). Edmund responds, defending Fanny's understanding of value, saying “That is hardly Fanny's idea of a family assembling. If the master and mistress do not attend themselves, there must be more harm than good" (89).

Yet the novel does more than merely support this understanding of a landowner's responsibilities. Austen goes a step further by demonstrating, through Fanny, that 
personal improvement results from keeping with the legacy of an estate. By remaining faithful to the traditional role of a landowner, one could also become morally deserving of holding a claim to that land. Fanny ruminates during a reflection on the grounds of Mansfield that "there would be less [wickedness and sorrow] if... people were carried more out of themselves by contemplating such a scene" (117-118). For Fanny, as for many of Austen's women characters, the tree avenues hold that potential for moral transformation.

Although women can't own property, Austen develops her characters in relationship to responsible ownership and garden improvements. The shrubberies in Pride and Prejudice and Mansfield Park illustrate contrasting settings established by the women who go there. In Pride and Prejudice, Elizabeth sustains her dignity against Lady Catherine. In Mansfield Park, the frivolous women characters enjoy the shrubbery only for beauty, while Fanny, on the other hand, establishes her responsibility through respect for the tree avenues. For Fanny, as for many of Austen's women characters, specific areas of the park estates develop specific moral qualities and contribute to the moral transformations of the protagonists. 


\section{Austen's Call For Stewardship}

England's Regency Era marked an evolution in previously conceived notions of land ownership within upper class English society. Austen's women protagonists reveal problems with privatized land ownership during this century's move from the community common to enclosure and vain improvements of now privately demarcated property. Her protagonists combat the vanity of eighteenth-century male property owners by utilizing the tree avenues to voice a lost moral sense of responsibility towards land.

According to Harold Fromm, "classical writers were unwittingly doing ecocriticism for centuries before the genre burst forth onto the academic scene...noticing that they were living on and from the primal mud of earth" (Fromm 1). Austen was conscious of a shift in awareness away from the environment. According to modern ecocritical thought, "The environment does not wrap around the person for his regal contemplation: the person is the environment and the environment is the person" (Fromm 2). For Austen, frivolous improvement causes concern because the landowner has lost this sense of personal connection to their land. Austen's focusing on a strong connection between her protagonists and the tree avenues suggests a hope on her part that people can still resume this severed connection by becoming morally deserving.

Austen's acknowledgment that problems might accompany such a shift exhibits her forward thinking. Her concerns were valid and reach us still today, in a world burgeoning with toxins, pollution, erosion, changing weather patterns, chemicals, etc. Her foresight demands our respect and her works our attention, not because of her premise about her time, but because of the applicability of that premise to our current problems. 


\section{References}

Austen, Jane. Emma. New York: Signet Classic, 1996. Print.

---.Mansfield Park. New York: Bantam Dell, 2008. Print.

---.Northanger Abbey. New York: Signet Classic, 1996. Print.

---. Persuasion. New York: Tom Doherty Associates, LLC, 1999. Print.

---. Pride and Prejudice. New York: Tom Doherty Associates, LLC, 1994. Print.

Banfield, Ann. "The Moral Landscape of Mansfield Park." Nineteenth-Century Fiction. 26.1. June 1971: 1-24.

Bate, Jonathan. The Song of the Earth. Massachusetts: Harvard University Press, 2000. Print.

Batey, Mavis. Jane Austen and the English Landscape. Chicago: Barn Elms, 1996. Print.

Bell, Susan Grog. "Women Create Gardens in Male Landscapes: A Revisionist Approach to Eighteenth Century English Garden History." Feminist Studies. 16.3. Autumn 1990: 471-491.

Berry, Sue. "Pleasure Gardens in Georgian and Regency Seaside Resorts: Brighton, 1750-1840." Garden History. 28.2. Winter 2000: 222-230.

Bodenheimer, Rosemary. "Looking at the Landscape in Jane Austen." Studies in English Literature, 1500-1900. 21.4. Autumn 1981: 605-623.

Brown, Lloyd W. "Jane Austen and the Feminist Tradition." Nineteenth-Century Fiction. 28.3. December 1973: 321-338.

Chan, Mary M. "Location, Location, Location: The Spaces of Pride \& Prejudice." Persuasions: The Jane Austen Journal Online. 27.2. June 2007.

Cosgrove, Denis. "Prospect, Perspective and the Evolution of the Landscape Idea." Transactions of the Institute of British Geographers. 10.1. 1985: 45-62.

Duckworth, Alistair M. "Mansfield Park and Estate Improvements: Jane Austen's Grounds of Being." Nineteenth-Century Fiction. 26.1. June 1971: 25-48.

Easton, Celia. "Jane Austen and the Enclosure Movement: The Sense and Sensibility of Land Reform." Persuasions: Journal of the Jane Austen Society of North America. 24. 2002: 71-89.

Fromm, Harold. "Ecocriticism's Big Bang: A Review of Practical Ecocriticism: Literature, Biology and the Environment by Glen A. Love." Hudson Review. 56.1. 2013: 110. 
Gillis, Christina Marsden. "Garden, Sermon and Novel in Mansfield Park: Exercises in Legibility." Novel: A Forum on Fiction. 18.2. Winter 1985: 117-125.

Hart, Francis R. "The Spaces of Privacy: Jane Austen." Nineteenth-Century Fiction. 30.3. December 1975: 305-333.

Hobhouse, Penelope. Plants in Garden History: An Illustrated History of Plants and Their Influences on Garden Styles- From Ancient Egypt to the Present Day. London: Pavilion Books LTD, 2004. Print.

Jarrett, Derek. "The Regency Crisis of 1765." The English Historical Review. 85.335. April 1970: 282-315.

Kagawa, P. Keiko. "Jane Austen, The Architect: (Re)Building Spaces at Mansfield Park." Women's Studies. 35.2. March 2006: 125-143.

King, Amy M. Bloom: The Botanical Vernacular in the English Novel. Oxford University Press: Oxford. 2003. Print.

Lowenthal, David. "English Landscape Tastes." Geographical Review. 55.2. April 1965: 186-222.

Myers, Sylvia H. "Womanhood in Jane Austen's Novels." Novels: A Forum on Fiction. 3.3 Spring 1970: 225-232.

Pidduck, Julianne. "Of Windows and Country Walks: Frames of Space and Movement in 1990s Austen Adaptations." Screen. 39.4. Winter 1998: 381-400.

Stafford, William. "The Gender of the Place: Building and Landscape in WomenAuthored Texts in England of the 1790s." Transactions of the Royal Historical Society. 6.13. 2003: 305-318.

Wenner, Barbara. "'I have just learnt to love a hyacinth': Jane Austen's Heroines in Their Novelistic Landscape." Persuasions: Journal of the Jane Austen Society of North America. 24. 2002: 90-101. 